\title{
Dramaturgia - Do fundo do poço se vê a lua
}

Entrevista com Joca Terron ${ }^{1}$

Por Marcos Bulhões

1. Quais os pontos de partida - conceitos, questões, imagens - que geraram o inicio do seu projeto dramatúrgico?'

A ideia de palimpsesto proposta pelo Antônio Araújo foi fundamental conforme percebíamos o bairro como um acúmulo de experiências étnicas, sociais etc. É claro que essa percepção só foi se aprofundando com o tempo e com as pesquisas, pois a memória do bairro - e nisto o Bom Retiro não difere de São Paulo num todo - não é bem preservada. A presença de uma atriz francesa no elenco, a Laetitia Augustin-Viguier, e sua dificuldade em visualizar as camadas de passado que coexistem ou que deveriam coexistir no lugar - a presença italiana, judaica etc. - me fez entender que precisaríamos "descascar" muito essas memórias, assim como se descasca a tinta de uma parede muitas vezes pintada, para chegarmos a algo de essencial.

Se contribuí em algo para o projeto, creio, foi no entendimento de que no Bom Retiro tudo passa (as correntes migratórias, os vendedores e compradores) menos as coisas, que ficam para trás em forma de lixo.

\section{O que muda no seu olhar sobre a cidade depois deste processo de trabalho a partir do bairro Bom Retiro?}

Sempre procurei olhar a cidade com lupa benjaminiana, e nisto não mudou muito. São Paulo pela sua multiplicidade em constante formação/deformação é um lugar que possibilita a experiência de se perder. É uma cidade onde tudo se encontra nesse permanente estado de construção/reconstrução, uma cidade que exige investigação permanente. Como diz uma amiga minha, São Paulo vai ser uma cidade muito bonita quando ficar pronta.

\footnotetext{
${ }^{1}$ É poeta, prosador e artista gráfico. Atuou como dramaturgo do espetáculo Bom Retiro 958 metros.
} 
3. Quais os limites e problemas do processo colaborativo de criação cênica do ponto de vista do dramaturgo?

O trabalho criativo em si é um problema que todo criador se impõe. Ou seja, um escritor quando escreve deve estar em conflito consigo mesmo, com suas incapacidades e limitações. Deve brigar sozinho, e em geral acaba apanhando. Criar coletivamente não é muito diferente. É bem positivo, nesse processo, existir uma crítica "a quente," feita na hora mesma da realização. Por outro lado, este tipo de processo sofre dos vícios do brainstorming, um excesso de ideias onde tudo está sob jugo sem que haja propriamente a figura de um juiz. Nisso, muita coisa legal vai pro ralo e muita ideia questionável permanece. E o teatro é muito mais pragmático, pois nele tudo tem que "funcionar". A literatura é menos assertiva, nesse sentido, ou pelo menos é assim com a literatura que mais me atrai, aquela que está completamente desprendida de compromisso com o mercado, às vezes inclusive com o leitor.

4. O que fica marcado, em sua memória de escritor, como momentos interessantes do desenvolvimento da sua escritura no espetáculo?

Houveram diversos momentos interessantes e o convívio criativo foi bom. Porém me arrependo um pouco de não ter minado a qualidade dessa convivência, de não ter incendiado o circo na defesa de algumas ideias, talvez o resultado geral fosse superior. Mas talvez não, impossível saber. De qualquer modo, aprendi muitíssimo acerca de como o uso do texto é compreendido quando contraposto a uma imagem, desse funcionamento complementar. No mais, a atividade de escrever é meio inútil, e estar envolvido num trabalho na qual a escritura ganha função é satisfatório. Pude provar da mesma satisfação que um encanador deve sentir ao corrigir um vazamento.

5. Do ponto de vista dos modelos dramatúrgicos mais tradicionais, centrados na narrativa, a sua dramaturgia em parceria. Com o Teatro da Vertigem pode ser criticada pelo excesso de fragmentação, por um discurso "demasiadamente aberto". Como você vê esse tipo de critica conservadora?

A crítica precisa tomar aulas de montagem, de justaposição e elipse. Ajudaria ir ao cinema e à galeria de arte com mais frequência. Assistir tevê, essas coisas. Por exemplo: eu não enxergo a estrutura de "Bom Retiro 958 Metros" como aberta. Porém entendo que há uma dificuldade em se compreender o texto, que sai perdendo ao competir com a qualidade visual do espetáculo e com a dispersão imposta pelo cenário de ruas repletas de interferências, etc. A melhor crítica que ouvi - considerei 
tudo o que foi publicado muito "comprometido", no sentido de que o ambiente teatral parecia aguardar o próximo passo do Vertigem como sendo uma imersão no campo da arte sem palavra, da instalação artística em movimento - foi a de um amigo que trabalha com circo. Ele disse: "Joca, o texto nessa peça não interessa. Se os atores em vez de falar o texto falassem "XYUTRSDEXZ" (grunhido) seria igualmente bom." Creio que isso diz tudo.

\section{No trabalho com a palavra o que te provoca desejo? 0 que te bloqueia?}

A transmissão de novidade. O que costuma me bloquear é a falta de imaginação alheia.

\section{Como você vê a fricção entre literatura e teatro?}

São campos muito distintos. Sempre compreendi a literatura como arte da imagem, e no espaço dramatúrgico o que acredito ser a maior qualidade de meu texto (seu apelo visual) se perde. Acredito, porém, que essa característica de meu trabalho literário contribuiu para a peça. Nela há, por exemplo, imagens sem palavras que foram criadas por mim. Igualmente, há textos que foram criados por outros, em geral pelos atores.

FIM 